\title{
New genera of philopotine spider flies (Diptera, Acroceridae) with a key to living and fossil genera
}

\author{
Jéssica P. Gillung ${ }^{1, \dagger}$, Shaun L. Winterton ${ }^{2, \ddagger}$ \\ I Universidade de São Paulo, Departamento de Zoologia, Instituto de Biociências, São Paulo, SP, Brazil \\ 2 California State Collection of Arthropods, California Department of Food \& Agriculture, Sacramento, Ca- \\ lifornia, USA \\ † urn:lsid:zoobank.org:author:97C1B803-BA98-4EBC-B400-C3289156E4EA \\ † urn:lsid:zoobank.org:author:37F5AC48-EC3A-47ED-902B-2BD1467CCA72 \\ Corresponding author: Shaun L. Winterton (wintertonshaun@gmail.com)
}

Academic editor: Torsten Dikow | Received 18 July 2011 | Accepted 16 August 2011 | Published 8 September 2011

urn:lsid:zoobank.org:pub:9366389E-42A3-464D-BD89-17CC80DC41D8

Citation: Gillung JP, Winterton SL (2011) New genera of philopotine spider flies (Diptera, Acroceridae) with a key to living and fossil genera. ZooKeys 127: 15-27. doi: 10.3897/zookeys.127.1824

\begin{abstract}
In this paper we describe two new genera of philopotine Acroceridae: Schlingeriella irwini gen. et sp. n. (New Caledonia) and Quasi fisheri gen. et sp. n. (Mexico). The Baltic amber species Eulonchiella eocenica Meunier, 1912 is rediagnosed and a neotype designated based on a newly discovered specimen. We also provide a dichotomous key to the world genera of Philopotinae, both living and fossil.
\end{abstract}

\section{Keywords}

Spider fly, Acroceridae, cybertaxonomy

\section{Introduction}

Spider flies (Diptera: Acroceridae) are a geographically cosmopolitan group although most species are relatively rarely collected. Most species feed at flowers and are likely important specialized pollinators as suggested by their frequently elongate proboscis (often equal to body length) and nectar feeding habits, although some species have reduced or even vestigial mouthparts (Schlinger 1981, 1987). Adults have a distinctive mor- 
phology and a wide diversity of form and colour, but usually with a small head, greatly enlarged lower calypter and swollen abdomen. Larvae are parasitoids of spiders, with a hypermetamorphic life cycle consisting of four instars (Schlinger 1981, 1987, 2009).

Acroceridae comprise over 520 described species in about 53 genera (Pape and Thompson 2011). The species are traditionally separated in three extant subfamilies Acrocerinae, Panopinae and Philopotinae, based on adult morphology and host specificity. Panopinae have been postulated as the most primitive and Acrocerinae the most derived, with Philopotinae supposedly occupying an intermediate position (Schlinger 1987). Phylogenetic analyses by Winterton et al. (2007) based on molecular data, however, do not corroborate this subfamilial arrangement, with Acrocerinae recovered as polyphyletic and Panopinae as a derived clade. The monophyly of Philopotinae has never been questioned based on a series of morphological synapomorphies (Schlinger 1981), a position also strongly supported by analyses of molecular data (Winterton et al. 2007). Adults of Philopotinae are characterized by enlarged postpronotal lobes that are usually contiguous dorsomedially to form a collar around the head, as well as varying degrees of arched body shape (Figs 1-7).

There are approximately 52 species and 14 genera in Philopotinae, both living and fossil, found in all major biogeographical regions. Two morphological groups are easily recognizable in the subfamily based on reduction of wing venation (i.e. number of wing cells and primary veins approximating wing margin). The first group comprises six genera with relatively complete wing venation and includes: Dimacrocolus Schlinger, 1961 (Madagascar), Eulonchiella Meunier, 1912 (Baltic amber), Helle Osten Sacken, 1896 (New Zealand), Megalybus Philippi, 1865 (Chile), Parahelle Schlinger, 1961 (Madagascar) and Thyllis Erichson, 1840 (South Africa and Madagascar). The second group comprises eight genera characterized by reduced wing venation such that cells $\mathrm{d}, \mathrm{bm}$ and even $\mathrm{m}_{3}$ are absent through reduction and loss of crossveins. The wings typically have only major veins radiating from cell br (Figs 1B, D). Genera in this group include Africaterphis Schlinger, 1968 (Africa), Archaeterphis Hauser \& Winterton, 2007 (Baltic amber), Oligoneura Bigot, 1878 (Palaearctic), Philopota Wiedemann, 1830 (South and Central America), Prophilopota Hennig, 1966 (Baltic amber), Quasi gen n. (Mexico), Schlingeriella gen n. (New Caledonia) and Terphis Erichson, 1840 (South America).

Eulonchiella eocenica Meunier, 1912 was briefly described and poorly illustrated by Meunier (1910) and (1912) from Baltic amber (only in the latter publication was the name Eulochiella eocenica applied for the first time). The holotype was deposited in the Albertus University Collection in Königsberg - Prussian territory at the time and now belonging to Russia - but was lost during the Second World War (Hennig 1966). Fortunately, Frank Hull made relatively more accurate drawings than Meunier and notes about the fossil during a visit to this collection prior to the war. Based on these unpublished data, Hennig (1966) redescribed and figured the species. Recently a specimen in the George Poinar collection, matching the original descriptions by Meunier (1910, 1912) and subsequent redescription and figure in Hennig (1966), has been identified as E. eocenica. This individual is also from Baltic amber deposits and is preserved in 
excellent condition. Herein we diagnose Eulonchiella eocenica and designate a neotype based on this newly discovered specimen. We also describe the new genera Schlingeriella irwini gen. et sp. n. from New Caledonia and Quasi fisheri gen. et sp. n. from Mexico, and provide a dichotomous key to all living and fossil genera of Philopotinae.

\section{Materials and methods}

Terminology follows McAlpine (1981) and Schlinger (1981). In most acrocerids, two crossveins span the area between the radial and medial sectors enclosing the cell $r_{4+5}$. The proximal crossvein is $\mathrm{r}-\mathrm{m}$, while the distal crossvein bisecting cell $\mathrm{r}_{4+5}$ (between wing veins $M_{1}$ and $R_{4+5}$, or rarely $R_{5}$ ) is referred to here as $2 r-m$ following Hardy (1946). Collections where specimens are deposited are as follows: Muséum National d'Histoire Naturelle, Paris, France (MNHN), California Academy of Science, San Francisco, USA (CAS), California State Collection of Arthropods, Sacramento, USA (CSCA) and Queensland Museum, Brisbane, Australia (QM). Descriptions were constructed using Lucid Builder 3.5, using a matrix database of character states, which were then exported using the natural language function into XML and a text document. Specimen images were taken at different focal points using a digital camera and subsequently combined into a serial montage image using Helicon Focus software. High-resolution digital images were deposited into Morphbank with embedded URL links within the document between descriptions and Morphbank images. All new nomenclatural acts and literature are registered in Zoobank (Pyle and Michel 2008).

\section{Taxonomy}

\section{Eulonchiella Meunier}

http://species-id.net/wiki/Eulonchiella

Figs 1E-G, 2

Eulonchiella eocenica Meunier 1912: 177 - Meunier 1910: 177, Brunetti 1926: 583, Hennig 1966: 7, Evenhuis 1994: 311. Type species: Eulonchiella eocenica Meunier, 1912: 177.

Type material. Neotype male, Baltic amber (\#DB 10-12) (CAS).

Diagnosis. Body shape arched; colouration non-metallic brown-black; head spherical, size slightly smaller than thorax width; eye bare; male frons narrowed; eyes contiguous above and below antennal base; posterior margin of eye rounded; proboscis length greater than head length; position of antenna in middle of frons; flagellum shape stylate; palpus present; thorax with postpronotal lobes enlarged, medially contiguous to form collar; legs not greatly elongated, tibial spines absent; pulvilli present; subscutellum slightly enlarged; wing hyaline, markings absent; costa ending in radial field; 

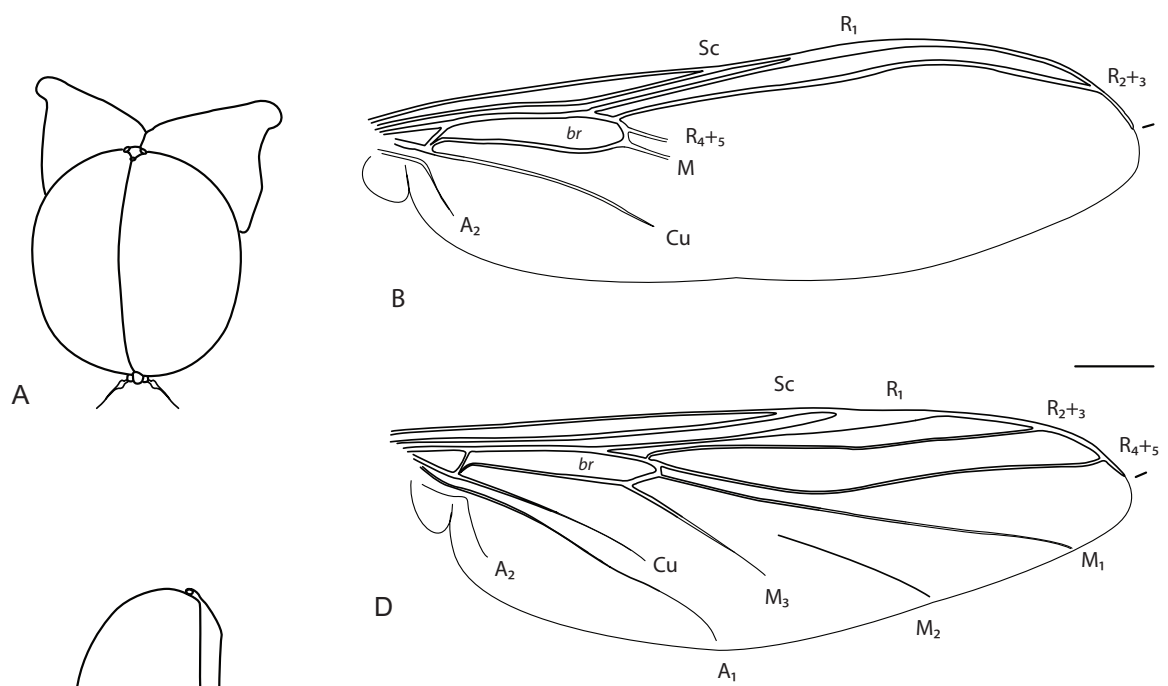

C
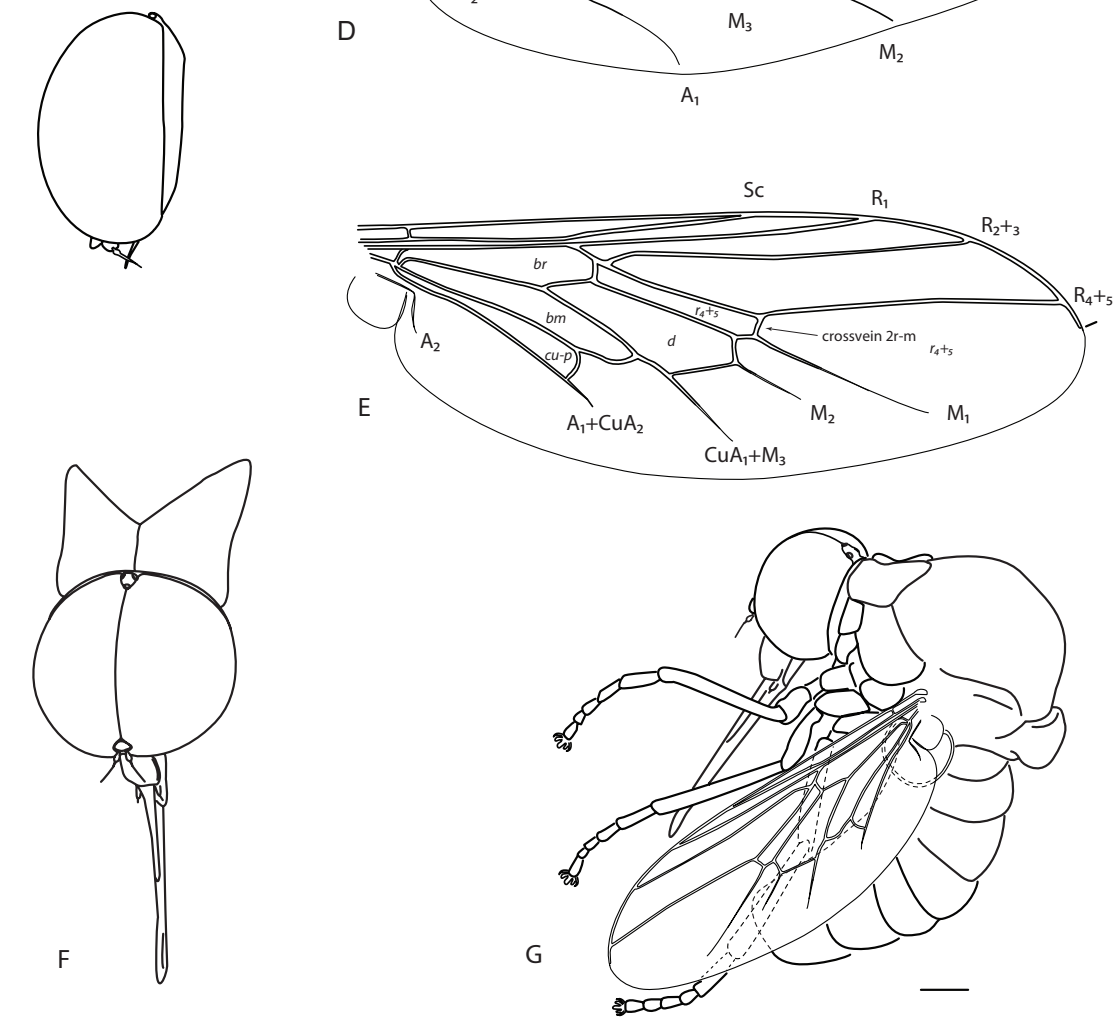

Figure I. Quasi fisheri gen. et sp. n. A head and postpronotal lobes, anterior B wing $\mathbf{C}$ head, lateral. Schlingeriella irwini gen. et sp. n. D wing. Eulonchiella eocenica Meunier E head and postpronotal lobes, anterior $\mathbf{F}$ habitus in situ, lateral. Scale line $=0.2 \mathrm{~mm}$.

costal margin straight in both sexes; humeral crossvein present; alula well developed; anal lobe not enlarged; $R_{2+3}$ present; $R_{4+5}$ present as single vein; radial veins meeting wing margin before wing apex; cell $\mathrm{r}_{4+5}$ bisected by crossvein $2 \mathrm{r}-\mathrm{m}$, narrow elongate; discal cell present, closed apically; medial veins $M_{1}, M_{2}$ and $M_{3}$ present; medial veins 


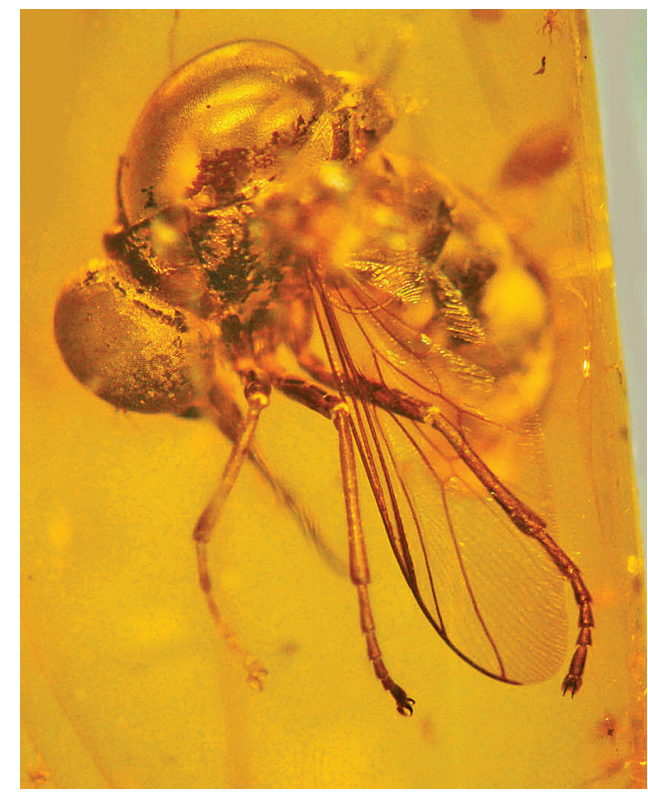

Figure 2. Eulonchiella eocenica Meunier (Baltic Amber). Body length = ca. $4.5 \mathrm{~mm}$.

tapered and faint towards margin; cell $\mathrm{m}_{3}$ absent; $\mathrm{CuA}$ joining $\mathrm{M}_{3}$ and petiolate, not reaching wing margin; $\mathrm{CuA}_{2}$ fused to $\mathrm{A}_{1}$, not reaching wing margin, petiolate; abdomen smooth, shape rounded, cylindrical, similar width to thorax.

Comments. The above diagnosis is based on a neotype male of Eulonchiella eocenica Meunier deposited in the Poinar collection (\#DB 10-12) (to be ultimately housed in CAS). Hennig (1966) discussed this monotypic genus based on drawings by Meunier (1910) and a drawing provided by Frank Hull (published in Hennig 1966) before the type was destroyed. The enlarged abdomen in the drawing by Hull indicates that the original type was a female. The specimen examined herein is a male based on the narrower abdomen, despite the genitalia being obscured by an opaque mass. Like many Baltic Amber taxa, Eulonchiella is closely related to a group of Afrotropical genera including Dimacrocolus, Parahelle and Thyllis (Hennig 1966), all with relatively complete wing venation. Eulonchiella can be differentiated from all other Philopotinae genera by the legs not being elongate, eyes not pilose, wing venation relatively complete, proboscis elongate and palpi being present.

\section{Quasi gen. n.}

urn:1sid:zoobank.org:act:CD9618A4-E458-4B16-A7D6-0D188D77042E http://species-id.net/wiki/Quasi

Figs 1A-C, 3-5

Type species. Quasi fisheri sp. n.

Diagnosis. Body shape arched; colouration non-metallic pale brown; head width slightly smaller than thorax width; shape hemispherical; postocular ridge and occiput 


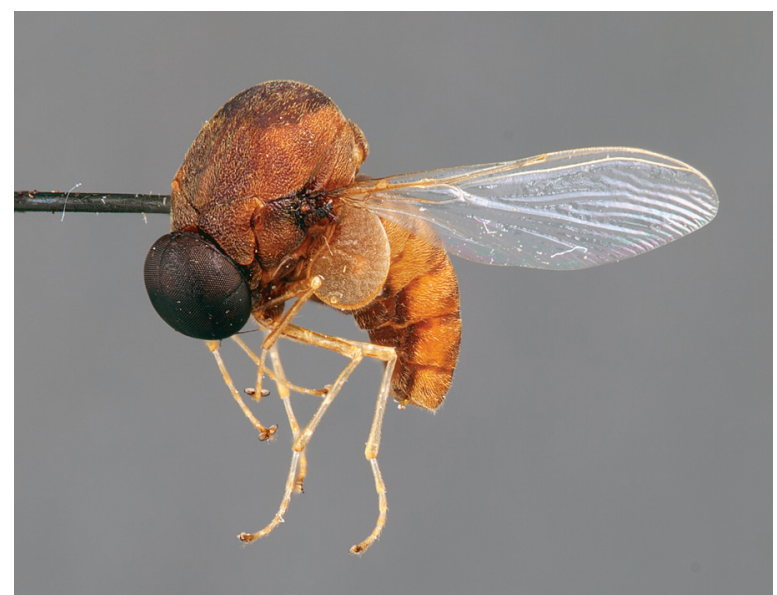

Figure 3. Quasi fisheri gen. et sp. n., male, anterolateral view [Morphbank: 693076]. Body length $=6.0 \mathrm{~mm}$.

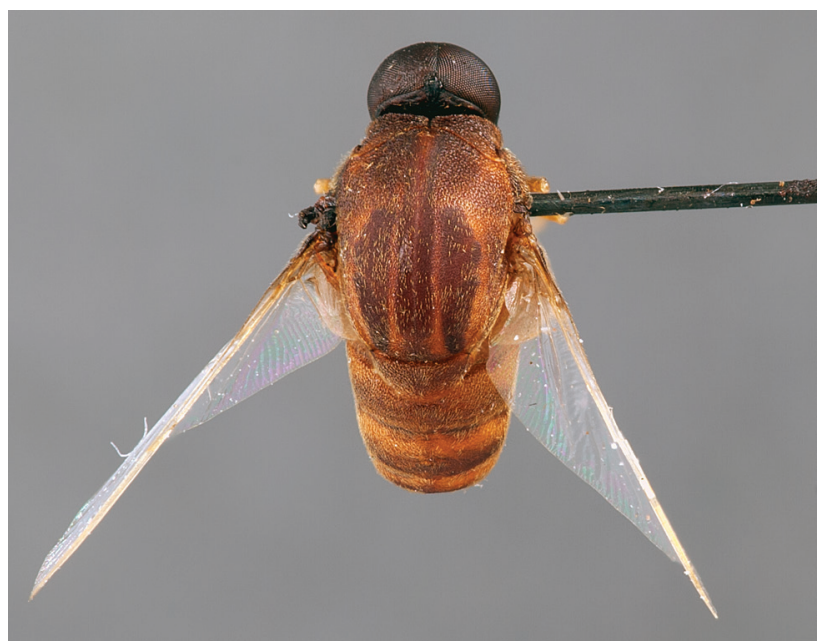

Figure 4. Quasi fisheri gen. et sp. n., male, dorsal view [Morphbank: 693077]. Body length $=6.0 \mathrm{~mm}$.

rounded; posterior margin of eye rounded; eyes bare; three ocelli present, medial ocellus slightly smaller; position of antennae on head nearer to mouthparts; eyes contiguous above antennal base, not contiguous below; palpi absent; proboscis much shorter than head length; flagellum shape stylate, apex with terminal seta; thorax with postpronotal lobes enlarged, medially contiguous to form collar; subscutellum not enlarged, barely visible; legs with tibial spines absent; pulvilli present; legs not greatly elongated; wing hyaline, markings absent; costa ending in radial field; costal margin straight; humeral crossvein absent; radial veins meeting wing margin before wing apex; $\mathrm{R}_{1}$ slightly inflated distally at pterostigma; $\mathrm{R}_{2+3}$ present, reaching wing margin; $\mathrm{R}_{4+5}$ present as very 


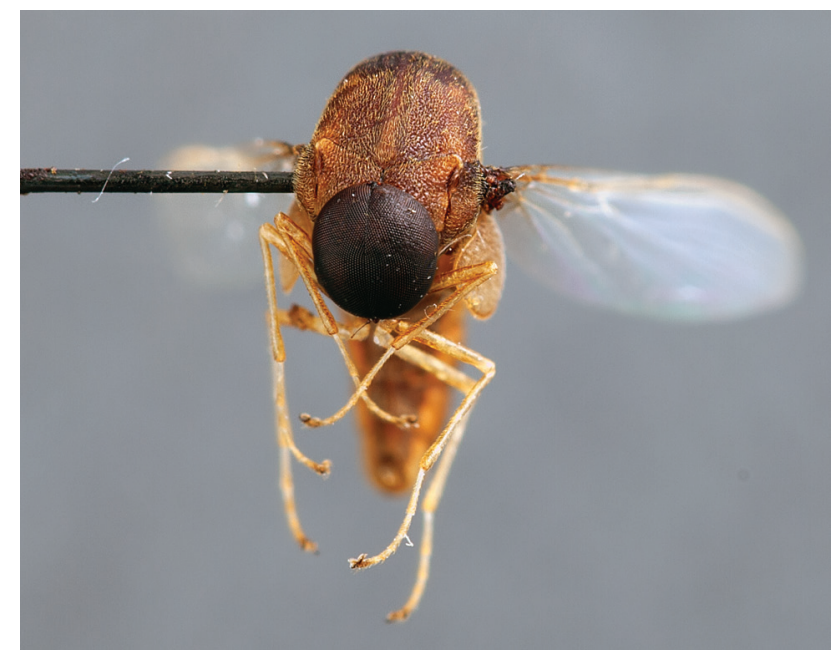

Figure 5. Quasi fisheri gen. et sp. n., male, anterior view [Morphbank: 693078]. Body length $=6.0 \mathrm{~mm}$.

short, single vein, not reaching wing margin; medial vein compliment with only one $M$ vein present; discal cell absent; medial vein very short, not reaching wing margin; cell $\mathrm{m}_{3}$ absent; crossvein $2 \mathrm{r}-\mathrm{m}$ absent; $\mathrm{Cu}$ reduced, not reaching wing margin; anal lobe not enlarged; alula well developed; abdomen smooth, shape rounded, cylindrical, similar width to thorax.

Etymology. Derived from Latin quasi, appearing as if resembling; referring to the likeness of this species to members of Terphis.

Comments. This genus is represented by only a single species $Q$. fisheri sp. n. from Veracruz, Mexico. It is closely related to Terphis and Philopota based on reduction in wing veins. The position of the antennae, proximate to the reduced mouthparts, reduced wing venation and absence of abdominal tubercles readily differentiates this genus from all other philopotine genera.

\section{Quasi fisheri sp. n.}

urn:lsid:zoobank.org:act:373C7B1F-51DF-4D7C-95FC-F91060433501

http://species-id.net/wiki/Quasi_fisheri

Type material. Holotype male, MEXICO: Veracruz: Córdoba, 12-25.vii.1964, E. Fisher, D. Verity [18.896, -96.923] (CSCA).

Description. Medium body size (male body: $6.0 \mathrm{~mm}$ ), male wing almost as long as the body (male wing: $5.3 \mathrm{~mm}$ ); Head. Eyes, antennae, face and occiput brown, occiput as narrow as the ocellar tubercle, ocelli brown, antennal tubercle brown and smaller than pedicel. Thorax. Postpronotal lobes, mesothorax, scutellum, subscutellum and coxae light brown with darker longitudinal markings, legs and lower calypter yel- 
lowish brown, pulvilli yellow, tarsal claws black, haltere yellow, wing hyaline with yellow veins. Abdomen. Tergites brown, with lateral margins yellow, sternites dark brown.

Male genitalia. The genitalia were not dissected because the holotype is the only specimen available. Genitalic dissection is not necessary to diagnose the genus, since it can be differentiated based on external characters.

Etymology. This species is named in honor of Eric Fisher, the collector of the only known specimen of this unusual species.

\section{Schlingeriella gen. $\mathbf{n}$.}

urn:lsid:zoobank.org:act:99EAC1BE-4A6F-43E0-B61A-6460BF68694E

http://species-id.net/wiki/Schlingeriella

Figs 1D, 6-7

\section{Type species. Schlingeriella irwini sp. n.}

Diagnosis. Body shape arched; colouration non-metallic dark brown; head width much smaller than thorax (female) or slightly smaller than thorax (male); head spherical; postocular ridge and occiput extended posteriorly into slight ridge; posterior margin of eye rounded; eyes bare; position of antennae on head near middle of frons, slightly nearer to mouthparts; eyes contiguous above antennal base, not contiguous below; palpi present; proboscis longer than head; antennal flagellum stylate, apex with terminal seta; thorax with postpronotal lobes enlarged, medially contiguous to form collar; subscutellum enlarged; legs not greatly elongated; tibial spines absent; pulvilli present; wing hyaline, markings absent; costa ending in radial field; costal margin straight in both sexes; humeral crossvein absent; radial veins meeting wing margin before wing apex; $R_{1}$ inflated distally at pterostigma; $\mathrm{R}_{2+3}$ present; $\mathrm{R}_{4+5}$ present as single vein, slightly curved anteriorly midway; veins $M_{1}, M_{2}$ and $M_{3}$ present; discal cell absent; medial veins reaching wing margin (or nearly so); cell $m_{3}$ absent; crossvein $2 \mathrm{r}-\mathrm{m}$ absent; $\mathrm{Cu}$ reduced, not reaching wing margin; anal lobe not enlarged; alula well developed; abdomen smooth, rounded, cylindrical in shape, similar width to thorax (male) or greatly rounded, inflated (female).

Etymology. This genus is named in honor of Evert I. Schlinger, not only a collector of specimens of this species, but a foremost expert on world Acroceridae taxonomy and patron of dipterology.

Comments. This genus is represented by only a single species ( $S$. irwini sp. n.) from New Caledonia. Winterton et al. (2007) included DNA sequences for this genus in their phylogenetic analysis of the family, placing it close to the New Zealand genus Helle. Schlingeriella gen n. can be differentiated from all other philopotine genera by a combination of the following characters: inflated vein $R_{1}$ apically, medial veins mostly reaching the wing margin, absence of all wing cells except cell $b r$, apilose eyes and elongate mouthparts. There is dramatic sexual dimorphism in body size, with females considerably larger than the diminutive males; males of this genus are some of the smallest acrocerids known. 


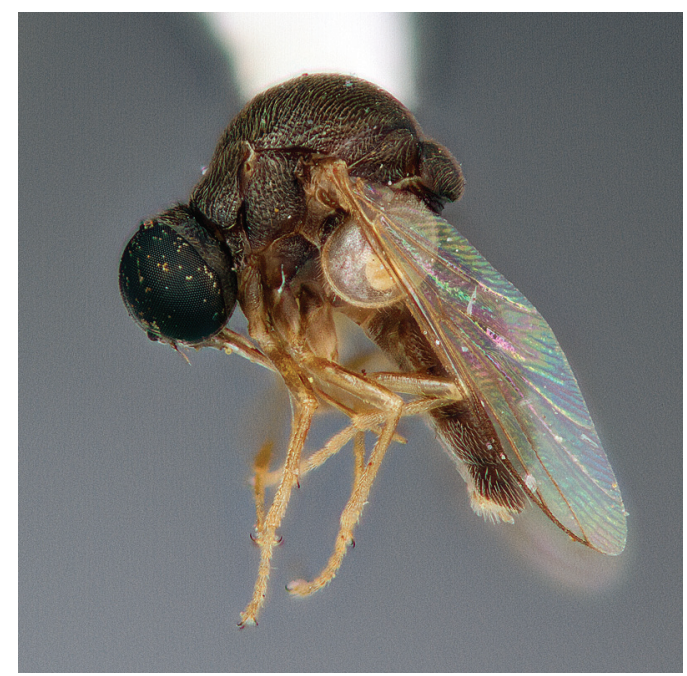

Figure 6. Schlingeriella irwini gen. et sp. n., male, lateral view [Morphbank: 693079]. Body length = $2.4 \mathrm{~mm}$.

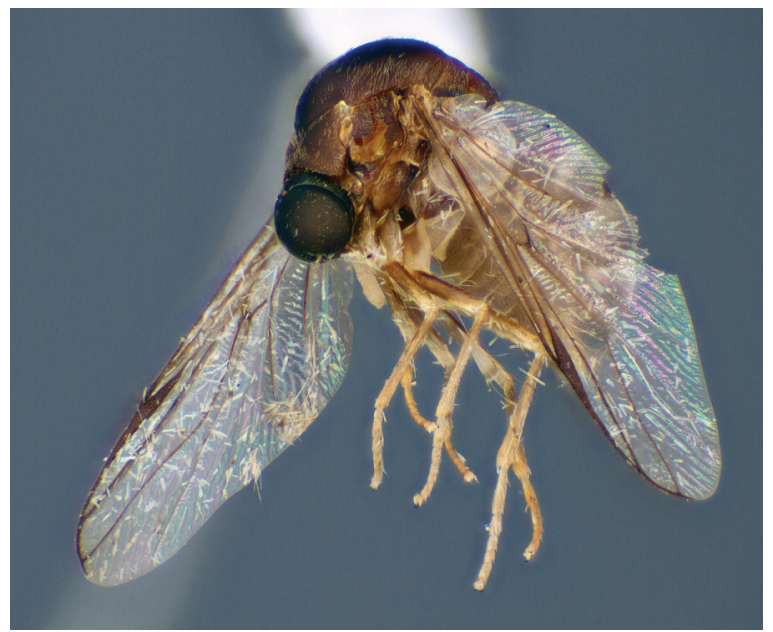

Figure 7. Schlingeriella irwini gen. et sp. n., female, lateral view [Morphbank: 693080]. Body length = $4.4 \mathrm{~mm}$.

\section{Schlingeriella irwini sp. $\mathrm{n}$.}

urn:lsid:zoobank.org:act:9AF204C7-FA7F-4DBC-B71D-4FFFCE367FB4 http://species-id.net/wiki/Schlingeriella_irwini

Genbank accessions. AY144402.1, AY140881.1, AF539888.1

Type material. Holotype male, New Caledonia: Riviere Bleue, refuse area, 700', 28.xi.1992 E. \& M. Schlinger, at Scaveola flower, prey of green crab spider [-22.112, 166.677] (MNHN) (EIS013911). 
Paratypes. New Caledonia: 3 males, 1 female, Riviere Bleue, same data as holotype (CAS, EIS013912, 013913) (CSCA, 013914, 013915); male, Riviere Bleue, 600', 19.6 km on Riviere Bleue Road. M.T., 16-17.xi.1992, E. \& M. Schlinger coll. (EIS013910); female, Riviere Bleue, 700', Malaise, 6-16.xi.1992, E. \& M. Schlinger, D. Webb; 1 male, 1 female [abdomen only], Mt. Nihgua, Nov. 2000, E. I. Schlinger \& L. J. Boutin [voucher specimens from Winterton et al. (2007)] (EIS007431, male; EIS011170, female) (CAS); 1 female, Col d'Amieu Forestry Camp, 450m 1718.x.1978, J. S. Dugdale, Malaise trap [-21.576, 165.740] (EIS013909) (CAS); 1 male, Mt. Ouin, 1100m, 9.xi.2002, C. Burwell \& G. Monteith, pyrethrum, trees \& logs $(-22.016,166.466)(\mathrm{QM})$.

Description. Male with small body size (male body: $2.4 \mathrm{~mm}$ ) and wing as long as the body (male wing: $2.5 \mathrm{~mm}$ ), female with medium body size (female body: $4.4 \mathrm{~mm}$ ) and wing longer than the body (female wing: $6.0 \mathrm{~mm}$ ). Head. Eyes, occiput and ocellar tubercle dark brown, occiput wider than the face; ocelli shining light brown, antennal tubercle shining black, antennae light brown, face black, clypeus shining brown, as long as the antennae, proboscis yellow. Thorax. Uniform dark brown with short whitish pile; coxae yellow, legs dark yellow, femora with darker yellow-brown suffusion, lower calypter and haltere pale yellow, wings hyaline with brown veins. Abdomen. Dark brown; female tergites I-II entirely brown, tergites III-VI with the anterior half yellow and the posterior half brown, sternites brown.

Etymology. This species is named in honour of Michael E. Irwin.

\section{Key to world genera of living and fossil Philopotinae}

1 Wing venation reduced, with only one basal cell (br) present (Fig. 1B, D) ...7

- Wing venation relatively complete, with additional cells $\mathrm{d}$, bm, cu-p and ba-

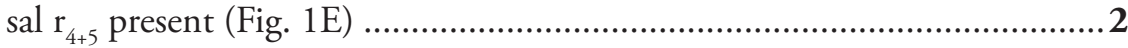

$2 \quad$ Palpi present ......................................................................... 4

Palpi absent.......................................................................... 3

3 Eyes densely pilose (South Africa and Madagascar) ... Thyllis Erichson, 1840

- $\quad$ Eyes very sparsely pilose or bare (Madagascar)..... Parabelle Schlinger, 1961

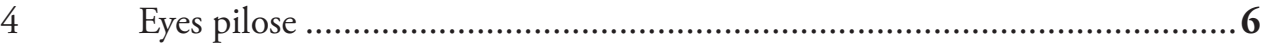

Eyes apilose......................................................................................5

5 Eyes contiguous below antennae; humeral crossvein present; vein $\mathrm{R}_{1}$ not inflated (Baltic amber) (Figs 1E-G, 2) ................Eulonchiella Meunier, 1912

- $\quad$ Eyes separate below antennae; humeral crossvein absent; vein $\mathrm{R}_{1}$ inflated at pterostigma (New Zealand)

Helle Osten Sacken, 1896

6 Legs relatively very long; male with tufted projection at the base of costa (Madagascar) Dimacrocolus Schlinger, 1961

- $\quad$ Legs of normal length; male without tufted projection at the base of costa (South America) Megalybus Philippi,1865

Eyes pilose 


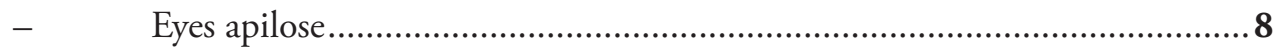

$8 \quad$ Mouthparts equal to, or longer than head length ......................................

- $\quad$ Mouthparts much shorter than head length ..............................................10

9 Wing veins reaching wing margin; $M_{2}$ not connected to $M$ vein, unsclerotized and discontinuous basally; vein $\mathrm{R}_{1}$ inflated at pterostigma (New Caledonia) (Figs 1D, 6-7) Schlingeriella gen. $\mathbf{n}$.

- Wing veins not reaching wing margin (Hennig 1966: Fig. 11), $\mathrm{M}_{2}$ originating on $M$ vein, sclerotized and continuous basally; vein $R_{1}$ not inflated at pterostigma (Baltic amber).

Prophilopota Hennig, 1966

10 Three pairs of tubercles present on segments II - IV of abdomen; occiput extended posteriorly to form an acute ridge (South America).

Terphis Erichson, 1840

- $\quad$ Abdomen without tubercles; occiput rounded, not extended posteriorly...11

11 Antenna on ventral side of head, adjacent to mouthparts; abdomen conical (Mexico) (Figs 1A-C, 3-5)

Quasi gen. n.

- $\quad$ Antennae on lower front side of head, but not adjacent to mouthparts; abdomen rounded (Africa)

Africaterphis Schlinger, 1968

12 Large hemispherical head; posterior margin of eye emarginate; mouthparts shorter than head; occiput rounded; postpronotal lobes proximate but not contiguous medially (Baltic amber).

Archaeterphis Hauser \& Winterton, 2007

- Head smaller and almost spherical, eye not emarginate posteriorly; mouthparts elongate, longer than head, occiput extended posteriorly to form acute ridge; postpronotal lobes contiguous medially......

Palpi present (Palaearctic)

Oligoneura Bigot, 1878

Palpi absent (Neotropical) Philopota Wiedemann, 1830

\section{Systematics of Philopotinae}

While two groups can be differentiated within Philopotinae based on reduction of wing venation, three clades have been identified by Winterton et al. (2007) largely corresponding to three biogeographical regions.

Philopota genus group- This genus group comprises Africaterphis from Africa, the Palaearctic Oligoneura, Archaeterphis and Prophilopota, and new world genera Philopota, Megalybus, Quasi gen n. and Terphis. Archaeterphis is a very distinctive genus, closely related to the extant genus Africaterphis (Hauser \& Winterton, 2007). Prophilopota is presumably more closely related to Oligoneura, since both genera share the presence of maxillary palpi and similar shape of the antennal tubercle (Schlinger, 1971). Quasi gen $\mathrm{n}$. is closely related to Philopota and in particular, Terphis. This genus shares with Terphis the insertion of the antennae on the lower side of head, reduced mouthparts, presence of relatively well-developed subscutellum and substantial reduction of the wing venation, the latter being less reduced in Philopota. In addition, both Philopota 
and Quasi gen n. lack the abdominal tubercles present in Terphis, and share a conical abdomen, instead of a swollen one that characterizes Terphis. Genera in the Philopota genus group are found in the northern and southern hemispheres with greater diversity in the New World (four genera). All genera in this group have reduced wing venation except Megalybus, the sister genus to the clade (Winterton et al. 2007).

Helle genus group- Schlingeriella gen $\mathrm{n}$. was included in the study by Winterton et al. (2007) as "undescribed genus New Caledonia". It is closely related to the New Zealand genus Helle, since they both have apilose eyes, well developed palpi, elongate mouthparts and an inflation of the vein $\mathrm{R}_{1}$ at the pterostigma. Schlingeriella gen $\mathrm{n}$. is differentiated from Helle by its small body size and the reduced wing venation.

Thyllis genus group- This group contains genera with complete wing venation including three Afrotropical genera (Dimacrocolus, Parahelle and Thyllis) and the Palaearctic genus Eulonchiella. Dimacrocolus and Parahelle are endemic to Madagascar while Thyllis is found in both Madagascar and South Africa.

\section{Acknowledgements}

The paper is dedicated to Dr. Evert I. Schlinger not only for his support and patronage of dipterology, but for his substantial work on Acroceridae over the previous decades. Thank you to Chris Grinter for assistance and help with organizing loans of specimens and to Martin Hauser for his assistance during the visit by J.G. to CSCA. Thank you to Norman Woodley and Martin Hauser for their comments on the draft manuscript. This paper is based upon work supported by the National Science Foundation (NSF) under DEB award number 0614213. Any opinions, findings, and conclusions or recommendations expressed in this publication are those of the authors and do not necessarily reflect the views of NSF.

\section{References}

Brunetti E (1926) New and little-known Cyrtidae (Diptera). Annals and Magazine of Natural History 18, 561-606.

Evenhuis NL (1994) Catalogue of the fossil flies of the world (Insecta: Diptera). Backhuys Publishers, Leiden. [iv] + 600 pp.

Hardy GH (1946) Miscellaneous notes on Australian Diptera. XII. Cyrtidae, Dolichopodidae and Phoridae. Proceedings of the Linnaean Society of New South Wales 71, 65-71.

Hauser M, Winterton SL (2007) A new fossil genus of small headed fly (Diptera: Acroceridae) from Baltic amber. Annals of the Entomological Society of America 100, 152-156. doi: 10.1603/0013-8746(2007)100[152:ANFGOS]2.0.CO;2

Hennig W (1966) Spinnenparasiten der Familie Acroceridae im baltischen Bernstein. Stuttgarter Beiträge zur Naturkunde 165, 1-21. 
Meunier F (1910) Sur un Cyrtidae de l'ambre de la Baltique. Bulletin de la Societe Entomologique de France 9, 177-179.

Meunier F (1912) Coup d'oeil retrospectif sur les dipteres du succin de la Baltique. Annales de la Societe Scientifique de Bruxelles 36, 160-186.

McAlpine JF (1981) Morphology and terminology-Adults. In: McAlpine JF, Peterson BV, Shewell GE, Teskey HJ, Vockeroth JR, Wood DM (Eds) Manual of Nearctic Diptera. Research Branch, Agriculture Canada Monograph 1: 9-63.

Pape T, Thompson FC (Eds) (2011) Systema Dipterorum, Version 1.0. http://www.diptera. org/ [accessed on $3^{\text {rd }}$ August 2011].

Pyle RL, Michel E (2008) Zoobank: Developing and nomenclatural tool for unifying 250 years of biological information. Zootaxa 1950, 39-50.

Schlinger EI (1971) The Acroceridae of Japan, Part I. Resurrection of the Philopotine genus Oligoneura Bigot, with a revision of the Japanese species and description of seven new species (Diptera). In: Hidaka Z (Ed) Entomological Essays to commemorate the retirement of Professor K. Yasumatsu. Hokuryukan Publ., Tokyo. vi + 185-200.

Schlinger EI (1981) Acroceridae. In: McAlpine JF, Peterson BV, Shewell GE, Teskey HJ, Vockeroth JR, Wood DEM (Eds) Manual of Nearctic Diptera. vol. I. Research Branch, Agriculture Canada. Monograph 27: 575-584.

Schlinger EI (1987) The biology of Acroceridae (Diptera): True endoparasitoids of spiders. In: Nentwig W (Ed) Ecophysiology of Spiders. Springer-Verlag, Berlin, 319-327.

Schlinger EI (2009) Acroceridae (spider flies, small-headed flies). In: Brown BV et al. (Eds) Manual of Central American Diptera: Volume 1. NRC Research Press, Ottawa, Ontario, Canada, 551-556.

Winterton SL, Wiegmann BM, Schlinger EI (2007) Phylogeny and Bayesian divergence time estimations of small-headed flies (Diptera: Acroceridae) using multiple molecular markers. Molecular Phylogenetics and Evolution 43, 808-832. 